\title{
Exploring participation in co-curricular activities among undergraduate students
}

Mulrooney, HM*.

School of Life Sciences, Pharmacy \& Chemistry, Kingston University, Penrhyn Road, Kingston-uponThames, London KT1 2EE.

*Corresponding author: hilda.mulrooney@kingston.ac.uk

Keywords: co-curricular, real-life learning, employability skills

\begin{abstract}
Co-curricular activities offer an opportunity for students to develop and demonstrate employability skills. Not all students take advantage of activities on offer, while others undertake multiple activities. In this study, second and third year students from two related undergraduate degree courses who had and had not taken up co-curricular activities identified their reasons for participating or not, and completed two questionnaires exploring their motivation (Academic Motivation Scale, AMS and Motivated Strategies for Learning Questionnaire, MSLQ). First year students identified which activities they would be interested in participating in in future years, and why. Clear differences in participation between the two degree courses were seen, with significantly higher levels of intrinsic motivation among students who participated. Among those who did participate compared with those who did not, significant differences in different types of motivation were seen. Self-efficacy was also significantly higher in those who did, compared with those who did not, participate, although whether this is a cause or a consequence of participation is unclear. First year students indicated interest in a range of co-curricular activities, for personal as well as academic reasons. Further work is needed to ensure that all students understand the relevance and importance of co-curricular activities.
\end{abstract}

\section{Introduction}

Employability is a major issue for students and institutions (Pegg et al., 2012). Embedding employability within higher education is a key priority (Higher Education Council for England (HEFCE), 2011) to ensure that graduates are equipped to meet workplace demands (Pegg et al., 2012). Producing graduates with skills and competencies which they can apply to real life challenges within the working world is a challenge within busy academic curricula. Cocurricular activities offer additional opportunities for students to develop and demonstrate employability skills. Co-curricular activities are usually voluntary and offered outside the curriculum but complement it (Higher Education Academy (HEA), 2015). Their value in helping students to bridge the gap between knowledge and its application is recognized (Winter et al, 2012, 2015; Andrews, 2013). However opportunities are only of use if students take advantage of them, so it is important to understand why students choose to participate or not.

Under the Nutrition umbrella at KU there are two separate but related degrees; the BSc Nutrition (Human Nutrition) and BSc Nutrition (Exercise and Health). Both are three year full time degrees, but they differ in their focus and emphasis. The BSc Nutrition (Exercise and Health) (NEH) is 50\% sport and exercise science (including psychology) and 50\% nutrition; while the BSc Nutrition (Human Nutrition) (Nut) focuses on nutrition, physiology and biochemistry and their application to health 
and disease. Both student groups take all core nutrition modules together; one each in first, second and final years. In addition the NEH students can take additional nutrition modules as options in the final year which are core to the Nut students. Traditionally the NEH students have allied themselves more with the sport and exercise part of the degree, and many have appeared to be less engaged with nutrition aspects. It is for this reason that the degree was recently rebranded as BSc Nutrition (Exercise \& Health) from its previous incarnation (BSc Exercise, Nutrition \& Health). It has also recently been accredited by the national professional organisation for nutritionists, the Association for Nutrition (AfN); both degrees are now accredited.

The National Student Survey (NSS) scores for nutrition were low prior to 2013 (e.g. 62\% overall satisfaction in 2012); with a hint that students' confidence in their ability to apply principles to practice was low. For example NSS question 21 'As a result of the course I feel confident in tackling unfamiliar problems' scored 70, 53 and 58\% respectively in 20102012. In order to tackle both these issues a strand of co-curricular activities was developed and has been offered on a voluntary basis to students since 2013. Within the co-curricular strand a range of activities have been made available, including writing book reviews, visits to relevant nutrition/sport organisations, relevant nutrition/sport external organisations visiting the university to deliver workshops, and talks and career-specific events delivered by former graduates. A public health strand has gained strength over time which includes health promotion activities, training of students as facilitators on a peer cookery education programme and the development of a cook book for students by students. However uptake of these voluntary activities is variable and it is often the same students who avail themselves of many of these valuable activities. This project aimed to understand who was taking up opportunities and why, the barriers to involvement for those who have chosen not to take part and what activities would interest students, to inform the future development of the strand.

\section{Methods}

Ethics approval for this project was given by the Centre for Higher Education Research \& Practice Research Ethics Committee, Kingston University.

A short in-class activity was developed for second and final year students (Levels 5 \& 6 respectively). This activity asked students to record if they had participated in co-curricular activities up to that point, if so which ones and their reasons for choosing those activities ('Yes' group). For those students who had chosen not to participate, their reasons for nonparticipation were recorded ('No' group). In addition each student completed the Academic Motivation Scale (AMS; Vallerand et al, 1992) and Motivated Strategies for Learning Questionnaire (MSLQ; Pintrich et al, 1993) to explore different types of motivation (both questionnaires) and additionally the types of learning strategies they employed (MSLQ only). Each student recorded their unique student number on the activity sheet and motivation questionnaires. All data from the inclass activity and questionnaires was coded and entered into an Excel spreadsheet. The unique student ID number was used to record age, gender and ethnicity of participants using the internal university database; once this information was entered into the spreadsheet the ID numbers were removed ensuring that data was anonymised from that point forward.

Level 4 students do not have the same opportunities to partake of co-curricular activities as the other year groups, since they have less nutrition knowledge to apply. Public health activities are not open to them for example. However they can attend talks and visits from external organisations as well as careers events. Level 4 students completed a short in-class activity to record which of the activities already on offer would interest them and why; in addition they could record any other activities they would like to see offered in the future.

All in-class activities were completed within core nutrition modules taken only by students of the nutrition degrees; completion of the inclass activity plus the questionnaires took approximately 25 minutes (Levels 5 \& 6); 
completion of the Level 4 in-class activity took approximately 15 minutes.

Since data was non parametric, anonymised data was analysed using Mann Whitney $U$ tests to explore differences between 'Yes' and 'No' groups, and differences in responses between course programmes. A chi-square test was used to determine whether there was a difference in participation between the Nut and $\mathrm{NEH}$ degree programmes. A significance level of $p<0.05$ was used in all tests.

Finally, attainment in core Level 4, 5 and Level 6 nutrition modules was mapped for both degree programmes for academic year 201617.

\section{Results}

\section{Participants:}

A total of 68 students participated, 34 Level 4 (50\% of total study sample), and 17 each at Levels 5 and 6 (25\% of total study sample each) (Table 1). A total of 56, 47 and 39 students were enrolled at Levels 4,5 and 6 respectively so this participation rate represented $61 \%, 36 \%$ and $44 \%$ of the total possible sample of nutrition students respectively.

\begin{tabular}{|l|c|c|c|}
\hline & \multicolumn{3}{|c|}{$\begin{array}{c}\text { Participants } \\
\text { Numbers (\%) }\end{array}$} \\
\hline Degree & Level 4 & Level 5 & Level 6 \\
\hline NEH & $11(32)$ & $4(24)$ & $9(53)$ \\
\hline Nut & $23(68)$ & $13(76)$ & $8(47)$ \\
\hline Total & $34(100)$ & $17(100)$ & $17(100)$ \\
\hline
\end{tabular}

Table 1 Descriptions of student participants by level.

\section{Involvement in co-curricular activities:}

Participation in co-curricular activities varied both between programmes and within levels of study. At Level 5, 10 students participated of whom 9 were Nut students, and at Level 6, 9 students participated of whom 6 were Nut students (Table 2). A chi square test of significance was performed to explore whether involvement in co-curricular activities differed by the degree programme. A statistically significant effect was seen $\left(x^{2} 4.54\right.$ (df 1$)$, $p=0.03$ ); participants were more like to be Nut than NEH students.

\begin{tabular}{|l|l|l|l|l|}
\hline & \multicolumn{2}{|l|}{ Level 5 } & \multicolumn{2}{l|}{ Level 6 } \\
\hline Degree & Yes & No & Yes & No \\
\hline NEH & $1^{*}$ & 2 & 3 & 6 \\
& $(10)$ & $(33)$ & $(33)$ & $(75)$ \\
\hline Nut & 9 & 4 & 6 & 2 \\
& $(90)$ & $(67)$ & $(67)$ & $(25)$ \\
\hline Totals & 10 & 6 & 9 & 8 \\
& $(100)$ & $(100)$ & $(100)$ & $(100)$ \\
\hline
\end{tabular}

Table 2 Participation ('Yes' group) and non-participation ('No' group) by level \& degree. *1 participant did not complete the questionnaire

\section{AMS results:}

Differences in responses to the AMS between 'Yes' and 'No' groups, and by degree programme were explored using Mann Whitney $U$ tests. No statistically significant results were seen between the 'Yes' and 'No' groups for any of the AMS areas. However intrinsic motivation was significantly higher in Nut compared with NEH students (respective means \pm SD $6.3 \pm 0.83$ vs. $5.59 \pm 0.82$ ); $\cup 69$ (df 32), $\mathrm{p}=0.012$.

\section{MSLQ results:}

Mann Whitney $U$ tests showed that extrinsic goal orientation was significantly higher in the 'Yes' compared with 'No' group (mean \pm SD respectively $6.46 \pm 0.48 \& 5.97 \pm 0.73$ ), $\cup 203$ (df 32), $p=0.033$. In addition, self-efficacy was significantly higher in the 'Yes' compared with the 'No' group (mean $\pm S D$ respectively $5.59 \pm 0.69$ \& 5.42 \pm 0.67 ), U 222 (df 23), $\mathrm{p}=0.006$. No other statistically significant differences were seen and there were no significant differences in the study techniques used, either between the 'Yes' and 'No' groups or the different degree pathways.

In Nut compared with NEH students, intrinsic goal orientation was significantly higher (mean \pm SD respectively $5.53 \pm 0.58$ compared with $5.03 \pm 0.69$ ), $U 109$ (df 38), $p=0.02$. No other statistically significant differences were seen by course of study.

\section{Level 4 students interest in co-curricular activities:}

34 Level 4 students completed the in-class activity. Of the listed activities, visits to other organisations and institutions were the most popular options, followed by Life after Kingston 
Exploring participation in co-curricular activities among undergraduate students

(graduate nutrition-specific career event), attending talks and/or events offered by external organisations within the university and cook and eat sessions. The least popular option was standing for office within the $\mathrm{KU}$ NutSoc, a KU Nutrition Society set up by and for Nutrition students (Table 3).

\begin{tabular}{|l|l|l|}
\hline Activity & $\begin{array}{l}\text { Interest } \\
\text { Numbers (\%) }\end{array}$ & Comments \\
\hline $\begin{array}{l}\text { Visits } \\
\text { event }\end{array}$ & $30(88)$ & 'Ideas, knowledge, experience, interesting' \\
\hline Talks/events & $28(82)$ & 'helpful deciding what to do' \\
\hline Cook \& Eat & $28(82)$ & 'learn new things, fascinating, career choices' \\
\hline $\begin{array}{l}\text { Food Matters Live } \\
\text { conference }\end{array}$ & $28(82)$ & 'very beneficial' \\
\hline $\begin{array}{l}\text { Member of university } \\
\text { NutSoc }\end{array}$ & $24(71)$ & 'build confidence \& knowledge' \\
\hline $\begin{array}{l}\text { Nutritional analysis of } \\
\text { recipes for cookbook }\end{array}$ & $22(65)$ & 'already a member, fun' \\
\hline $\begin{array}{l}\text { General careers } \\
\text { information \& events }\end{array}$ & $22(65)$ & $\begin{array}{l}\text { 'could do this by myself as revision' \& 'not very } \\
\text { good at this' }\end{array}$ \\
\hline Health promotion stands & $20(59)$ & $\begin{array}{l}\text { 'learn new things', 'build awareness' \& 'I like } \\
\text { health promotion' } \\
\text { 'gain extra experience' \& 'research is awesome' }\end{array}$ \\
\hline SADRAS* & $18(53)$ & $10(29)$ \\
\hline $\begin{array}{l}\text { Officer in university } \\
\text { NutSoc }\end{array}$ & 'doesn't offer many extras' \& 'enhances CV' \\
\hline
\end{tabular}

Table 3 Numbers (percentages) of Level 4 students who expressed interest in specific cocurricular activities \& related comments. *SADRAS is a staff:student research partnership, student participation is funded

\section{Themes arising from qualitative comments} made:

Some students were clear-eyed about the benefits of co-curricular activities for their CVs, knowledge and/or skills as evidenced by the following comments:

\section{'Gain extra experience' 'Enhances my CV' \\ 'Like health promotion' \\ 'Learn new things'.}

Many specifically mentioned career choices and information as important to them:

'Helpful deciding what to do'

'Career choices'

However others felt that careers information was less relevant to them as first year (Level 4) students:
The role of co-curricular activities in benefitting day-to-day life apart from study or future careers was also discussed:

\section{'Stuff that I can use in my own life'.}

Personal preferences appeared to be a major factor in deciding whether or not students were interested in engaging with specific cocurricular activities. Fifteen separate comments about liking to cook were made. In addition:

\section{'Like health promotion' 'Fun'}

However a lack of confidence in personal ability was also seen:

'Not very good at this'

'Mostly for level 5 \& level 6'. 


\begin{tabular}{|c|c|c|c|c|}
\hline Degree & \multicolumn{4}{|c|}{ Modules } \\
\hline & LS4006 $^{1}$ & LS5007 $^{2}$ & LS6009 $^{3}$ & LS6010 $^{4}$ \\
\hline Overall & $\begin{array}{c}56.1 \pm 13.9 \\
n=55\end{array}$ & $\begin{array}{c}50.8 \pm 21.1 \\
n=44\end{array}$ & $\begin{array}{c}63.3 \pm 15.2 \\
n=34\end{array}$ & $53.8 \pm 11.4, n=26$ \\
\hline Nut & $\begin{array}{c}58.0 \pm 15.1 \\
n=30\end{array}$ & $\begin{array}{c}50.0 \pm 19.0 \\
n=30\end{array}$ & $\begin{array}{c}58.6 \pm 14.1 \\
n=21\end{array}$ & $53.7 \pm 10.9, n=22$ \\
\hline NEH & $\begin{array}{c}54.0 \pm 12.8 \\
n=25\end{array}$ & $\begin{array}{c}44.0 \pm 21.0 \\
n=14\end{array}$ & $\begin{array}{c}70.7 \pm 15.0 \\
n=13\end{array}$ & $58.0 \pm 4.9, n=4$ \\
\hline
\end{tabular}

Table 4 Attainment of Nut and NEH students in nutrition modules at Levels 4,5 \& 6 for academic year 2016-17. ${ }^{1}$ Level 4 nutrition module, core for both degrees. ${ }^{2}$ Level 5 nutrition module, core for both groups. ${ }^{3}$ Level 6 nutrition module, core for both groups. ${ }^{4}$ Level 6 nutrition module, core for Nut \& optional for NEH

\begin{abstract}
Attainment in core nutrition modules for Level 5 \& 6 students by degree programme The average $\pm S D$ results for nutrition modules at Levels 4,5 and 6 by degree programme for the academic year 2016-17 is shown in table 4. For core Level 4 and Level 5 modules, average scores were higher for Nut than NEH students particularly for the Level 5 module. At Level 6, average attainment of NEH students was higher for both modules compared with that of Nut students.
\end{abstract}

\section{Discussion}

Anecdotally a clear difference has been observed in the level of involvement of Nut compared with NEH students; traditionally more Nut students have expressed an interest and many have taken part in multiple activities. This observation was mirrored in the results of this albeit small study where a significantly higher numbers of Nut students chose to involve themselves in co-curricular activities. Although numbers of participants were small, the results illustrate what we had observed over a number of years. Why this is the case is unclear. We recognise that some students may be gaining experience outside the university and therefore may not perceive the cocurricular activities as offering them additional benefits. However if co-curricular activities enhance employability skills, this lack of engagement is potentially an important issue for the future careers particularly of $\mathrm{NEH}$ students. The lack of interest that some NEH students expressed in the activities may in part reflect their historically greater interest in sport and exercise science than in nutrition. As a result many of the activities on offer may not have been seen as personally relevant. However it should be noted that even when sport and exercise specific events were held (e.g. external sports nutritionists delivering sessions within the university), registered attendance by NEH students was low. Many $\mathrm{NEH}$ students play individual or team sports, some at county level, and consequently have training commitments which may make attendance at co-curricular events difficult for them. However many Nut students support themselves by working, so the juggling of multiple commitments is not an issue solely for $\mathrm{NEH}$ students. We tend to make time for the things that matter most to us, so the issue of motivation is important to consider (Valerio, 2012).

Motivation is what drives us to take action (Ryan \& Deci, 2000). Most theories of motivation begin by distinguishing between intrinsic and extrinsic motivation. Intrinsic motivation is that which comes from within; a desire to partake in an activity simply for its own sake, for enjoyment or interest, for the challenge or to satisfy curiosity (Barry \& King, 2000). It is considered to be more powerful than extrinsic motivation, which comes from outside the individual e.g. in response to incentives (Sternberg \& Williams, 2002). Intrinsic motivation is associated with increased interest and responsibility for one's own learning (Deci et al., 1991; Deci et al., 1999; Gottfried et al., 2001), and widely recognised as a powerful learning tool (Knowles et al., 2005). Extrinsic motivation lies between amotivation and intrinsic motivation and extrinsic motivation can be subdivided into 
more or less autonomous forms (Kusurkar et al, 2010), the more autonomous forms lying closer to intrinsic motivation than those which are less autonomous (Ryan \& Deci, 2000).

The reasons that students engage in academic tasks are examined in the MSLQ using three subscales; intrinsic goal orientation (with a focus is on mastery \& learning), extrinsic goal orientation (with a focus is on grades achieved \& approval from others) and task value (how interesting, useful or important the material is considered to be) (Duncan \& McKeachie, 2010). Compared with students who did not participate, 'Yes' students had significantly higher levels of extrinsic goal orientation compared with 'No' students $(p=0.034)$. Extrinsic goal orientation complements intrinsic goal orientation; a high value suggests that engagement in a task represents a means to an end (Pintrich et al, 1991). This result suggests that part of the motivation for involvement in co-curricular activities among those that participated was a recognition that doing so would benefit them in terms of grades or be seen by others as positive. It is unsurprising that a range of factors motivate those who take part, and that motivation is both extrinsically and intrinsically driven. Variation in both level and type of motivation is recognised (Ryan \& Deci, 2000), and within higher education both internal and external stimuli are likely to act as motivators (Pew, 2007). Even if external factors initially motivate students to take part in co-curricular activities, it is likely that the information gathered, skills mastered or topics discussed may enhance their intrinsic motivation so that involvement becomes selfperpetuating. While incentives can be used in teaching they should be used carefully to enhance intrinsic motivation or help to develop student competencies (Schunk et al, 2002), and these results suggest that external incentives such as improved grades did not undermine intrinsic motivation or competency development. A range of motivating factors may explain why some students undertake multiple different co-curricular activities, as observed in our student sample.

In this study, levels of intrinsic motivation as measured by the AMS (Vallerand et al, 1992) were significantly higher in Nut compared with $\mathrm{NEH}$ students, suggesting that Nut students perceived the activities to be meaningful and valuable in their own right, not simply as a means to an end. This perception may explain why significantly more Nut students engaged in co-curricular activities. The finding that intrinsic goal orientation (measured by MSLQ) was significantly higher in Nut compared with $\mathrm{NEH}$ students further supports the suggestion that Nut students value the activities on offer for their own sake, and participate to support their learning and gain mastery.

Self-efficacy is defined as perceived ability to undertake a task (Bandura, 1977; 1997), and it is a critical factor in motivation (Artino, 2012). While there were no differences in levels of intrinsic motivation as measured by either AMS or MSLQ between 'Yes' and 'No' groups, selfefficacy measured by the MSLQ was significantly higher in 'Yes' than 'No' groups. What is unclear is the direction of the relationship; whether those with greater selfefficacy feel more able to volunteer for cocurricular activities or whether involvement in co-curricular activities enhances self-efficacy. In reality it is likely to be a mixture of the two. Feelings of competence in an activity will enhance intrinsic motivation to engage in the activity because they satisfy a basic psychological need for competence (Deci \& Ryan, 1985; Ryan \& Deci, 2000). However they will only do so if autonomy is also supported (Deci \& Ryan, 2000). The fact that these activities are voluntary and engagement in them is self-directed is autonomy-supportive and likely to support intrinsic motivation (Deci \& Ryan, 2000); several of the activities themselves also allow students to develop activities and resources, which supports autonomy. Allowing students choice and control within learning environments enhances intrinsic motivation (Williams \& Williams, 2011). It is likely that participation in the cocurricular strand will become compulsory in the future to meet the requirements of professional accreditation. Without care there is a risk that this may actually undermine student intrinsic motivation. However in our view these activities are important in building student confidence, enhancing their engagement, gaining experience for their CVs and learning to apply principles to practice. Students who do not engage in them are disadvantaged; even if their academic performance does not suffer they will not gain 'real life' experience which is difficult to replicate within taught programmes. 
In light of both these factors the teaching team has decided to make completion of a minimum of two co-curricular activities per year mandatory in future. This will still allow students choice in which activities and types of activities with which they choose to engage, which we hope will help enhance their intrinsic motivation while simultaneously ensuring that all students gain from their involvement. To help our students understand the benefits of different activities, we also intend to map out the specific skills and competencies that they will gain from each activity against the skills \& competencies framework of the AfN. This will explicitly relate involvement to key employability and professional skills, and help students to identify specific benefits of participation.

Students entering our degree programmes come from a range of backgrounds and via different routes. The majority are young adults, with a small proportion of mature students each year. Both Nut and NEH students have to meet similar entry criteria in terms of points; however the Nut students tend to have stronger science backgrounds than NEH students, many of whom have stronger sport and psychology backgrounds. Academic attainment of both degree programmes for nutrition modules as shown in Table 4 shows that for Level 4 and 5 modules the Nut students achieved higher average scores, while the opposite was seen at Level 6 . However results in each year are at least partly a function of the cohort of students and the Level $6 \mathrm{NEH}$ students were particularly high achievers in 2016-17. In addition the final year module LS6010 is optional for NEH students so only those most interested in nutrition chose to take it and therefore they were more likely to do better. It is more usual to see lower attainment in nutrition modules in $\mathrm{NEH}$ compared with Nut students. Within LS5007 for example, 2 Nut students (7\%) failed the module compared with 7 (50\%) of the NEH cohort in the summer exams. We do not have attainment data for Yes and No groups specifically since records of attendance were not kept for all events and some events were also open to other student groups. However the nutrition teaching team know which of their students took part in multiple activities especially those which required higher levels of commitment and engagement with staff (e.g. SADRAS research projects and facilitating the peer cookery sessions). These students tended to be higher achievers academically. It could be argued that the strongest students are more likely to be involved in co-curricular activities because they recognise their value. But equally it may be the high achieving cohort of Level $6 \mathrm{NEH}$ students gained experience outside the university and therefore chose not to participate in the co-curricular activities we offered. It is the participation of less academic students in these activities which may be more important, especially if they are not already involved in extra-curricular activities. Looking at academic achievement is interesting but is not the complete picture, since co-curricular activities enhance student attainment in many ways.

Responsibility for motivation of adult learners lies with the adult (Rachal, 2002); the role of the teacher is in providing a learning environment which facilitates this (Pew, 2007). Understanding which activities are of interest to students and making them accessible therefore should enhance their motivation. Most Level 4 students wished to partake of cocurricular activities and preferences for several types of activities were shown. Qualitative data collected in this study suggests that students were influenced both by enjoyment ('fun') and extrinsic factors related to study ('enhances my CV'). Importantly, their personal lives external to the university also featured ('stuff I can use in my own life'). Helping students to find personal meaning and worth in taught materials influences their motivation (Deci \& Ryan, 1985). Drawing from the everyday allows learners to develop the skills to solve complex problems using and applying a variety of resources (Brown et al., 1989), and enables students to use and apply their own life experience and knowledge, which is considered by some to be the basis of learning (Kolb, 1984).

With regard to the lower level of engagement of NEH students with co-curricular activities, their programme has recently been accredited by the professional organisation for registered nutritionists in the UK, the Association for Nutrition

(http://www.associationfornutrition.org/Portals/ O/Public/Accreditation/2017\%2004\%2012\%20 Accredited\%20Undergraduate\%20Degrees $\%$ 20by\%20Subject\%20Area.pdf). This plus the 
recent rebranding of the $\mathrm{NEH}$ degree as a Nutrition degree may help future students to understand both the personal and professional relevance of nutrition-focused co-curricular activities. In addition feedback from Level 4 students demonstrates that personal preference also plays a part in student engagement; clearly not all the activities are perceived as equally attractive. A range of activities will continue to be offered, the benefits of participation will be outlined within the Personal Tutor Scheme, and both Nut and $\mathrm{NEH}$ students will be required to keep a log of their involvement in co-curricular activities, including those provided within the university and those which students access externally to give a more complete picture of the experience our students are gaining.

This study is small in terms of numbers of students involved, but offers some insight into the uptake of a new co-curricular strand among students, most of whom are young adults. Making the strand compulsory in future will ensure that all students have the chance to benefit and this will be important particularly for weaker students.

\section{Conclusions}

There is encouraging interest in the cocurricular strand among students. However not all students are equally interested and clear differences between the two nutrition degrees were seen. Differences in attitudes to individual activities were also seen. Those who participated in co-curricular activities had higher levels of self-efficacy and were motivated by both internal and external factors. Nut compared with NEH students had significantly higher levels of intrinsic motivation. Work is needed to ensure that all students understand the importance and relevance of co-curricular activities, particularly as these are likely to contribute towards demonstration of employability skills.

\section{References}

Andrews, M. (2013) Why our students need cocurricular, not extra-curricular, activities. Retrieved from The Guardian website: http://www.theguardian.com/higher-educationnetwork/blog/2013/jan/22/studentdevelopment-university-curriculum-design
Artino, A.R. (2012) Academic self-efficacy: from educational theory to instructional practice. Perspect. Med. Educ. 1:76-85. DOI: 10.1007/s40037-012-0012-5.

Bandura, A. (1977) Self-efficacy: toward a unifying theory of behavioral change. Psychol. Rev. 84:191-215.

https://www.uky.edu/ eushe2/Bandura/Bandu ra1977PR.pdf

Bandura, A. (1997) Self-efficacy: the exercise of control. New York: W. H. Freeman and Company.

Barry, K. \& King, L. (2000) Beginning Teaching and Beyond (3rd edn). Katoomba, NSW: Social Science Press.

Brown, J.S., Collins, A. \& Deguid, P. (1989) Situated cognition of learning. Educ. Res. 18: 32-42.

http://links.jstor.org/sici?sici=0013189X\%28198901\%2F02\%2918\%3A1\%3C32 \%3ASCATCO\%3E2.0.CO\%3B2-2

Deci, E.L. \& Ryan, R.M. (1985) Intrinsic motivation and self-determination in human behavior. New York: Plenum.

Deci, E.L., Vallerand, R.J., Pelletier, L.G. \& Ryan, R. (1991) Motivation and education: the self-determination perspective. Educational Psychologist, 26(3-4): 325-346. DOI: 10.1207/s15326985ep2603\&4_6

Deci, E.L., Koestner, R. \& Ryan, R.M. (1999) A meta-analytic review of experiments examining the effects of extrinsic rewards on intrinsic motivation. Psychological Bulletin, 125(6): 627668.

DOI: 10.1037/0033-2909.125.6.627

Duncan, T.G. \& McKeachie, W.J. (2010) The making of the Motivated Strategies for Learning Questionnaire. Educational Psychologist 40(2): 117-128. DOI: 10.1207/s15326985ep4002_6

Gottfried, A.E., Fleming, J. \& Gottfried, A.W. (2001) Continuity of academic intrinsic motivation from childhood through late adolescence: a longitudinal study. J. Educational Psychologist, 93(1): 3-13. DOI: 10.1037/0022-0663.93.1.3 
Exploring participation in co-curricular activities among undergraduate students

Higher Education Academy (HEA, 2015) Relevant Knowledge Hub Content. https://www.heacademy.ac.uk/knowledgehub/co-curricular-activities

Higher Education Council for England (HEFCE, 2011) Opportunity, choice and excellence in higher education. Bristol: HEFCE.

http://www.hestem.ac.uk/sites/default/files/hef ce opportunity choice and excellence in hi gher education.pdf

Knowles, M.S., Holton, E.F. III \& Swanson, R.A. (2005). The Adult Learner: The Definitive Classic in Adult Education and Human Resource Development (6th ed.). Burlington, MA: Elsevier.

Kolb, D.A. (1984) Experiential learning. Prentice-Hall: New Jersey, USA.

Kusarkar, R., Croiset, G., Kruitwagen, C. \& ten Cate, O. (2010) Validity evidence for the measurement of the strength of motivation for medical school. Adv in Health Sci Educ. DOI: 10.1007/s/10459-010-9253-4.

Pegg, A., Waldock, J., Hendy-Isaac, S. \& Lawton, R. (2012) Pedagogy for employability. York: HEA.

file:///C:/Users/User/Downloads/pedagogy for employability update 2012\%20(1).pdf

Pew, S. (2007) Andragogy and Pedagogy as Foundational Theory for Student Motivation in Higher Education. Insight Student Motivation, 2: 14-25.

http://files.eric.ed.gov/fulltext/EJ864274.pdf

Pintrich, P.R., Smith, D.A.F., Garcia, T. \& McKeachie, W.J. (1991) A Manual for the Use of the Motivated Strategies for Learning Questionnaire (MSLQ). Technical Report No. 91-B-004. University of Michigan; U.S. Dept. of Education, Office of Educational Research and Improvement, Educational Resources Information Center Ann Arbor, Mich.: [Washington, DC].

http://files.eric.ed.gov/fulltext/ED338122.pdf

Pintrich, P.R., Smith, D.A.F., Duncan, T. \& McKeachie, W.F. (1993) Reliability and predictive validity of the Motivated Strategies for Learning Questionnaire (MSLQ). Educ.
Psychol. Meas., 53: 801-813 DOI: $10.1177 / 0013164493053003024$.

Rachal, J.R. (2002) Andragogy's detectives: A critique of the present and proposal for the future. Adult Education Quarterly, 52(3): 21027.

http://www.uwyo.edu/aded5050/5050unit10/a ndragog.pdf

Ryan, R.M. \& Deci, E.L. (2000) Intrinsic and Extrinsic Motivations: Classic Definitions and New Directions. Contemporary Educational Psychology, 25: 54-67. DOI:10.1006/ceps.1999.1020

Schunk, D., Pintrich, P. \& Meece, J. (2002) Motivation in Education: Theory, research and applications (3rd edn). Upper Saddle River, NJ: Pearson-Merrill.

Sternberg, R.J. \& Williams, W.M. (2002) Educational Psychology. Boston, MA: Allyn \& Bacon.

Valerio, K.M. (2012) Intrinsic motivation in the classroom. Journal of Student Engagement: Education Matters, 2 (1): 30-35. http://ro.uow.edu.au/jseem/vol2/iss1/6?utm s ource=ro.uow.edu.au $\% 2 \mathrm{Fiseem} \% 2 \mathrm{Fvol} 2 \% 2 \mathrm{Fi}$ ss1\%2F6\&utm medium=PDF\&utm campaign =PDFCoverPages

Vallerand, R.J., Pelletier, L.G., Blais, M.R., Briere, N.M., Senecal, C. \& Vallieres, E.F. (1992) The Academic Motivation Scale: a measure of intrinsic, extrinsic and amotivation in education. Educ. Psychol. Meas. 52: 10031017. DOI: $10.1177 / 0013164492052004025$

Williams, K.C. \& Williams, C.C. (2011) Five key ingredients for improving student motivation. Research in Higher Education Journal, 11:

http://www.aabri.comwww.aabri.com/manuscri pts/11834.pdf

Winter, J., Sjerps-Jones, H., Dexter, B. \& Klaff, J. (2012) Informal learning for sustainability. In: Putting the ' $S$ ' into ED: Education for Sustainable Development in Educational Development. D. Cotton, S. Sterling, V. Neal and J. Winter (Eds) London: SEDA special.

Winter, J., Sterling, S. \& Cotton, D. (2015) 7 Steps to: Embedding Sustainability into 
Exploring participation in co-curricular activities among undergraduate students

Student Learning. Education Development, Plymouth University.

https://www.plymouth.ac.uk/uploads/productio n/document/path/3/3409/595997 2613967

Steps to Embedding Sustainability into Stu dent Learning 1214 BOLD.pdf 